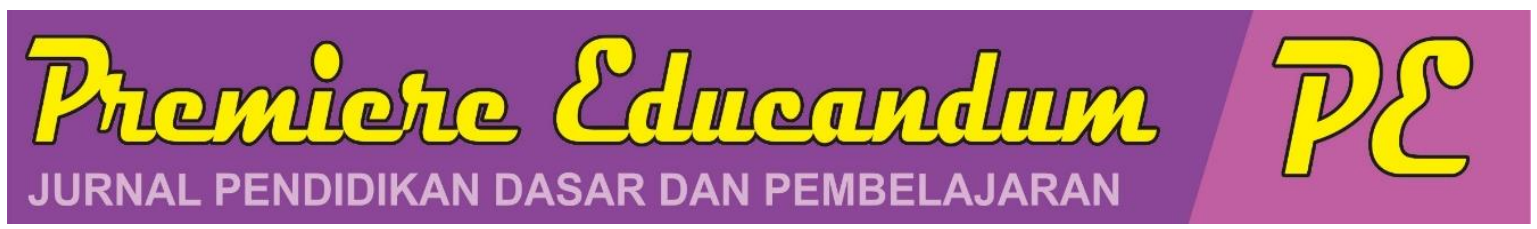

Premiere Educandum: Jurnal Pendidikan Dasar dan Pembelajaran

Volume 8(1) 41 - 53 Juni 2018

Copyright (22018 Universitas PGRI Madiun

ISSN: 2088-5350 (Print) / ISSN: 2528-5173 (Online)

Available at: http://e-journal.unipma.ac.id/index.php/PE

Doi: $10.25273 /$ pe.v8i1.2255

\title{
Model pembelajaran nilai-nilai toleransi untuk anak sekolah dasar
}

\author{
Nusi Nuswantari \\ Universitas PGRI Madiun \\ email: nusinuswantari@gmail.com
}

\begin{abstract}
Abstrak
This research aims are to identify the problems of social interaction among elementary school students and developing the design of conceptual tolerance education model appropriate with the their needs. The research employs research and development approach. The first step begins with the survey for needs assessment, the next step is developing module of tolerance learning. The respondents include 21 elementary school students and 24 teachers from 3 different elementary schools in Madiun. One school represents public elementary school and the other two represent private school. The data collecting methods included questionnaires, interview and focus group discussion. The data collected through descriptive and qualitative, then used as considerations in designing the tolerance education model. Those are collected through focus group discussion in improving the tolerance education model. The results of the research were: (1) there is a wide gap between the teacher expectation and the student condition, (2) The tolerance learning model is assessed to have activity material according to the learning objectives (3) The selection of appropriate learning strategy and method and have high visibility can be implemented in elementary school and teachers perceive the need for tolerance in elementary school although there are variations in delivery strategies, ie as intracurricular, extracurricular and inserted in subjects other than Civic.
\end{abstract}

Keywords : Learning Model, Tolerance Values, Elementary School students

\begin{abstract}
Abstrak
Tujuannya adalah untuk mengidentifikasikan berbagai persoalan dalam interaksi sosial siswa Sekolah Dasar dan mengembangkan rancangan konseptual model pembelajaran toleransi yang sesuai dengan kebutuhan anak Sekolah Dasar. Pendekatan penelitian ini dengan recearch and development. Tahap pertama dengan survey untuk need assesment, tahap kedua pengembangan modul pembelajaran toleransi. Responden 21 siswa Sekolah Dasar dan 24 guru wali kelas yang berasal dari tiga Sekolah Dasar di Madiun. Satu sekolah mewakili Sekolah Dasar Negeri dan dua sekolah mewakili Sekolah Dasar swasta. Pengumpulan data dengan metode angket, wawancara dan diskusi kelompok. Analisis data dengan deskriptif kualitatif, selanjutnya dijadikan sebagai bahan pertimbangan untuk mendesain model pembelajaran nilai-nilai toleransi. Data hasil diskusi kelompok terfokus digunakan untuk perbaikan disain model pembelajaran nilai-nilai toleransi. Kesimpulan penelitian ini adalah (1) terdapat kesenjangan yang cukup lebar antara harapan guru dengan kondisi siswa (2) Modul pembelajaran nilai-nilai toleransi dinilai memiliki materi aktivitas yang sesuai dengan tujuan pembelajaran, (3) Pemilihan strategi dan metode pembelajaran yang tepat dan memiliki visibilitas yang tinggi dapat dilaksanakan di Sekolah Dasar dan semua guru memandang perlunya pembelajaran toleransi di Sekolah Dasar, walaupun terdapat variasi perbedaan strategi penyampaian, yakni sebagai kegiatan intrakurikuler, ekstrakurikuler dan disisipkan dalam mata pelajaran selain PPKN.
\end{abstract}

Kata Kunci: Model Pembelajaran, Nilai-Nilai Toleransi dan Usia Sekolah Dasar

Histori artikel : disubmit pada 18 Februari 2018; direvisi pada 23 Maret 2018; diterima pada 21 Mei 2018 


\section{A. PENDAHULUAN}

Pendidikan toleransi dewasa ini menjadi tuntutan bagi bangsa Indonesia yang multi kultural. Berbagai peristiwa kerusuhan dan ketegangan sosial yang terjadi di negara ini, pada tingkat tertentu menunjukkan bahwa perilaku tidak toleran sangat dominan dalam hubungan sosial. Interaksi sosial merupakan hal yang sangat mendasar di dalam kehidupan manusia. Interaksi sosial pertama kali terjadi di dalam keluarga, seiring dengan perkembangan lingkungan sosial seseorang, interaksi sosial dapat terjadi dilingkup yang lebih luas yaitu di lingkungan sekolah, lingkungan bermain dan lingkungan masyarakat.

Menurut Knapp dikatakan bahwa interaksi sosial dapat menyebabkan seseorang menjadi dekat dan merasakan kebersamaam, atau sebaliknya dapat menyebabkan menjadi jauh dan terpisah dari hubungan interpersonal (Ling, 2002) Apakah seseorang akan berhasil secara memuaskan dalam interaksi sosialnya, tidak terlepas dari sikap toleransi yang dimilikinya. Toleransi mencakup toleransi yang bersifat sosial dan bersifat pribadi. Toleransi sosial sangat diperlukan dalam interaksi sosial dengan lingkungannya, sedangkan toleransi pribadi diperlukan untuk menghadapi stresor peristiwa hidup yang dialaminya. Keduanya penting dalam kehidupan seseorang. Sehingga setiap orang dapat menumbuhkan sikap toleransi sedini mungkin.

Penumbuhan sikap toleransi ini dapat dilakukan oleh orang tua dalam keluarga, dan dapat dilakukan oleh guru disekolah. Peran guru di sekolah memiliki pengaruh yang sangat penting pada masa pertengahan dan masa akhir anak-anak. Guru merupakan simbol otoritas di kelas dapat menciptakan iklim kelas, dan menciptakan kondisi interaksi di antara siswa. Sehingga dalam beberapa hal dapat dikatakan bahwa hampir semua kehidupan setiap orang dipengaruhi oleh guru.

Menghadapi tuntutan kurikulum yang begitu padat, penuh dan lebih didominasi pada pengembangan aspek kognitif semata, seringkali menjadikan guru memenuhi tuntutan yang ketat untuk penguasaan materi pelajaran. Pendekatan ini mengakibatkan terabaikannya aspek kepribadian kurang tergarap secara baik. Sangat mungkin pada akhirnya pendidikan yang demikian hanya dapat menghasilkan manusia-manusia yang pandai, namun tanpa diimbangi dengan moral yang baik, kepribadian yang integratif. Banyaknya kasus tindak kekerasan dikalangan anak-anak merupakan bukti nyata bahwa anak-anak tidak memiliki toleransi yang memadahi. Lembaga-lembaga pendidikan belum mampu memfasilitasi terbentuknya komunitas teman sebaya yang dapat saling mendukung dalam proses pertumbuhan dan pengembangan karakter.

Disinilah pentingnya para guru lebih memahami bahwa tanggung jawab mereka bukan sekedar menyampaikan materi pembelajaran, melainkan juga memfasilitasi proses pertumbuhan anak di sekolah dalam komunitas teman sebaya. Perilaku tidak toleran dapat mendorong seseorang melakukan tindak kekerasan. Berangkat dari uraian tersebut, maka permasalahan yang akan dikaji adalah bagaimanakah model pembelajaran nilai-nilai toleransi yang 
sesuai dengan kebutuhan anak-anak di sekolah dasar.

Berdasarkan uraian latar belakang maka secara umum penelitian ini bertujuan untuk mengembangkan model pembelajaran nilai-nilai toleransi anak usia sekolah dasar. Tujuan ini akan dicapai melalui serangkaian penelitian yang terdiri dari dua tahapan penelitian, yaitu untuk:

1. Mengidentifikasi berbagai persoalan dalam interaksi sosial antar siswa di sekolah Dasar.

2. Mengembangkan rancangan

konseptual model pembelajaran toleransi yang sesuai dengan kebutuhan anak usia sekolah dasar.

Manfaat dari penelitian ini adalah dapat memberikan sumbangan pemikiran dan usulan kebijaksanaan yang dapat diimplementasikan bagi pengembangan ilmu pendidikan, yaitu berupa metode intervensi pembelajaran yang mampu menstimulasi pertumbuhan dan perkembangan kepribadian anak menuju kepribadian integratif. Hal ini sejalan dengan apa yang dikatakan oleh (Nuswantari, 2017) bahwa kebijaksanaan akan sekedar sebagai impian atau rencana bagus yang tersimpan rapi dalam arsip ababila tidak diimplementasikan. Selain itu dapat memberikan sumbangan pemikiran bagi pembangunan manusia Indonesia seutuhnya, yaitu dengan melalui pembentukan character building yang dilakukan sejak dini di institusi sekolah dasar. Sedangkan pembentukan character building ini sangat diperlukan sebagai upaya pencegahan tindak kekerasan dan bekal kesiapan ketrampilan individu untuk hidup bersama dalam masyarakat Indonesia yang multikultural.
Pendidikan karakter bertujuan membentuk setiap pribadi menjadi insan yang berkeutamaan. Pendidikan karakter sebagai sebuah pedagogi memberikan ruang pertumbuhan bagi setiap individu dalam lembaga pendidikan untuk bertumbuh secara integral sebagai manusia yang menghayati nilai, khususnya nilai-nilai moral, nilai religius dan nilai-nilai kewarganegaraan. Dengan sikap toleransi individu menghadapi keadaan yang tidak sesuai dengan harapannya tidak akan secara spontan mengatakan perasaan negatifnya, melainkan ia akan berusaha menerima hal tersebut sabagai suatu hal yang pantas dihargai. Lebih jauh (Vogt, 1997) menjelaskan bahwa toleransi merupakan ketrampilan dan pemahaman yang diperlukan oleh setiap individu untuk dapat bertahan dalam dunia yang penuh dengan keragaman. (Green, 2001) juga menyatakan bahwa anak belajar bersikap toleran maupun tidak toleran dari lingkungan rumah, sekolah dan media. Sehingga toleransi dapat dikembangkan dengan cara meningkatkan pemahaman tentang diri sendiri dan pemahaman terhadap orang lain. Dengan adanya toleransi ini individu akan lebih menghargai perbedaan yang seringkali menjadi pemicu munculnya konflik.

Pembelajaran nilai toleransi anak sekolah dasar perlu memperhatikan karakteristik yang dimiliki anak usia tersebut, baik dari segi kognitif, moral maupun psikososial. Piaget mengemukakan bahwa dari segi kognitif usia anak-anak sekolah dasar memasuki tahap "operasional konkret" dalam berfikir (Santrock, 2002). Pada tahap ini anak tidak lagi memandang konsep sebagai suatu yang samar-samar dan tidak jelas, sebagaimana pada awal masa 
anak-anak. Pada tahap ini anak mulai mampu menghubungkan arti baru dengan konsep yang lama berdasarkan apa yang dipelajari setelah masuk sekolah. Anak mulai mendapatkan arti konsep baru dari media masa, misalnya radio, televisi dan film. Konsep-konsep sosial seperti menolong, menghargai, menghina dan memfitnah juga sudah mulai dikenal oleh anak. Bahkan sampai pada tingkat tertentu konsep-konsep sosial yang terkait dengan konsep stereotipe, prasangka dan diskriminasi mulai dikaitkan dengan agama, ras, seks ataupun kelompok sosial ekonomi yang berbeda.

Piaget juga mengatakan bahwa anak usia antara 5 - 12 tahun mampu mengaitkan konsep keadilan dengan tindak pelanggaran moral. Pada tahap ini pengertian yang kaku dan keras tentang benar dan salah yang telah dipelajari dari orang tua, menjadi berubah dan pada tingkat tertentu anak mulai memperhitungkan keadaan-keadaan khusus di sekitar pelanggaran moral (Santrock, 2002). Demikian juga penelitian (Purwanti, 2007) pada anak sekolah dasar menunjukkan bahwa tingkat perkembangan penalaran moral ternyata tidak selalu sejalan dengan tingkat kecerdasan intelektualnya. Temuan (Purwanti, 2007) ini sekaligus dapat menjelaskan fenomena kasus-kasus orang pandai tetapi tidak bermoral.

Sementara itu dari segi psikososial, anak pada masa akhir perkembangannya meningkat minatnya terhadap aktivitasaktivitas teman. Sehingga pada masa ini perkembangan anak disebut dengan usia berkelompok, yang ditandai dengan adanya kecenderungan untuk berteman. Keinginan anak untuk ingin selalu bersama kelompoknya menjadi semakin kuat. Sehingga muncul yang disebut dengan "geng anak" . Efek keanggotaan kelompok dapat membantu proses sosialisasi anak, dan dapat membantu dalam pengenalan dan aplikasi nilai-nilai yang ada di masyarakat.

Pemerintah dalam hal ini sudah membuat kebijakan dalam bidang pendidikan, yaitu memasukan pendidikan toleransi kedalam pendidikan Kewarganegaraan. Penyelenggaraannya mulai dari pendidikan dasar sampai di Perguruan Tinggi. Namun kompetensi yang diharapkan melalui kurikulum muatan lokal belum dapat mengakomodasi kepentingan semua siswa yang berlatar belakang berbeda Kompetensi Learning to live together lebih banyak menekankan pada aspek kognitif, sehingga kurang menghasilkan pengalaman nyata yang mendukung perkembangan aspek afektif kepribadian siswa dalam interaksi social secara damai dan toleran. Hal ini mungkin disebabkan oleh ketidak tepatan dalam menggunakan model pembelajaran. Hal ini sesuai dengan apa yang dikatakan oleh (Nuswantari, 2017) bahwa pelaksanaan kebijaksanaan adalah suatu yang penting daripada pembuatan kebijaksanaan.

Menurut Harefa (2004) dijelaskan bahwa budi pekerti dan pembentukan karakter memiliki sifat-sifat seperti integritas, kerendahan hati, tenggang rasa atau toleransi, kesederhanaan dan sebagainya, tidak dapat dilakukan lewat pengajaran. Pengajaran itu menyangkut masalah teori, sedangkan pendidikan sepenuhnya menyangkut masalah potensi. Sementara (Vogt, 1997) mengemukakan bahwa pendidikan toleransi dapat dilakukan dengan dua model, yaitu model pendidikan toleransi langsung (direct) dan model pendidikan 
toleransi tidak langsung (indirect). Model yang pertama menekankan pada interaksi sosial secara langsung antar kelompok siswa (intergroup contact) yang beragam latar belakangnya. Model ini mengharuskan keragaman latar belakang siswa dalam proses pembelajaran. Model yang kedua menekankan pada pengembangan kepribadian (personality development) para siswa yang terbuka terhadap perbedaan. Penerapan model pendidikan toleransi bukan saja dijenjang pendidikan menengah dan pendidikan tinggi, tetapi juga di jenjang pendidikan dasar. Menurut (Vogt, 1997) pendidikan toleransi dibeberapa negara memiliki pengaruh yang cukup signifikan terhadap penurunan kuantitas terjadinya sikap stereotip, prasangka, dan perilaku diskriminatif. Disisi lain model pendidikan toleransi pada tingkat tertentu dapat berdampak pada sikap penerimaan para siswa terhadap siswa lain yang berbeda etnik, warna kulit, agama dan gaya hidupnya.

Model pendidikan toleransi di Indonesia sudah mulai diselenggarakan sejak beberapa tahun terakhir oleh berbagai Lembaga Swadaya Masyarakat (LSM) untuk mendukung proses integrasi bangsa. LKIS (Lembaga Kajian Islam dan Sosial) telah menyelenggarakan program Belajar Bersama (BB) Islam Transformatif dan Toleran, yang ditujukan pada pemuda dan mahasiswa, terutama aktivis organisasi. Program Belajar Bersama (BB) Islam Transformatif dan Toleran terdiri dari tiga tema, yaitu : (a) Islam dan Gender (b) Islam dan Politik Kewarganegaraan, (c) Islam dan Relasi Agama. Program ini menggunakan empat prinsip utama, yaitu (a) belajar dari pengalaman, (b) terbuka dan jujur, (c) refleksi, (d) dialogis, dan salah satu tujuannya adalah transformasi sosial, penghormatan hak-hak asasi dan penghargaan pada pluralisme (Salim, 2003).

Program yang diselenggarakan oleh LKIS jelas sangat penting dalam konteks penanaman nilai-nilai toleransi kepada khalayak sasaran. Namun demikian, yang menjadi persoalan adalah bahwa program dari lembaga tersebut sebenarnya mahal (biaya ditanggung oleh penyelenggara dan tidak melibatkan partisipasi lembaga mitra, dan kurang berkelanjutan (banyak tergantung pada lembaga penyandang dana). Sementara itu, pendidikan toleransi seharusnya dapat diakses oleh kelompok sasaran yang lebih luas, agar peluang keberhasilan pendidikan toleransi menjadi semakin tinggi. Selain itu, untuk mencapai sasaran yang lebih luas, pendidikan toleransi perlu dirancang sedemikian rupa, sehingga tidak mahal, dapat mencapai masyarakat yang lebih luas, dan dapat dilaksanakan oleh berbagai sekolah dasar secara bekelanjutan.

\section{B. METODE PENELITIAN}

Penelitian ini menggunakan pendekatan research and development. Langkah awal dalam penelitian Tahap pertama dimulai dengan survey need assessment di sekolah dasar. Berdasarkan need assessment diidentifikasi berbagai persoalan yang terjadi dalam interaksi sosial siswa. Langkah kedua adalah pengembangan modul pembelajaran toleransi yang disusun sesuai kebutuhan siwa. Responden terdiri 21 siswa, dan 24 guru wali kelas yang berasal dari tiga sekolah dasar di Madiun. Sekolah Dasar yang terpilih ditentukan dengan pertimbangan heterogenitas variasi sifat (ciri) : satu 
sekolah mewakili ciri sekolah dasar negeri, dan dua sekolah mewakili sekolah dasar swasta.

Pengumpulan data dilakukan melalui 4 (empat) metode, yaitu : (a) angket untuk guru bidang studi, (b) angket untuk kepala sekolah, (c) wawancara dengan siswa, dan (d) diskusi kelompok terfokus dengan para pakar. Data yang terkumpul melalui wawancara dan angket dianalisis secara deskriptif kualitatif. Hasil analisis menjadi bahan pertimbangan untuk mendesain model pembelajaran nilai toleransi. Data dari diskusi kelompok terfokus digunakan untuk perbaikan desain model pembelajaran nilai-nilai toleransi.

\section{HASIL DAN PEMBAHASAN}

Terdapat tiga hal utama dalam pembahasan ini, yaitu pertama : identifikasi berbagai persoalan yang terjadi dalam interaksi sosial siswa sekolah dasar. Pada identifikasi ini tercakup bahasan tentang gambaran keadaan di sekolah baik keadaan saat ini maupun keadaan yang diharapkan. Kedua: uraian berlanjut pada pembahasan mengenai rancangan konseptual modul pembelajaran toleransi, yang dimulai dengan penetapan kompetensi yang dibutuhkan beserta strategi pembelajaran. Ketiga: penyusunan materi pembelajaran dalam bentuk draft modul yang telah dikaji oleh para pakar.

\section{Identifikasi persoalan interaksi sosial siswa di sekolah dasar}

Identifikasi persoalan dilakukan melalui langkah analysis kebutuhan yang merupakan langkah awal dalam konsep ADDIE (Analysis, Design, Development, Implementation, Evaluation). Konsep ADDIE merupakan landasan berpikir desain pembelajaran yang menggunakan pendekatan sistem (Prawiradilaga, 2007).

Wawancara dengan 21 siswa dilakukan untuk eksplorasi data yang difokuskan pada 4 pertanyaan utama, yaitu : (1) dengan siapa anak bisa bermain, (2) apakah anak mempunyai kecenderungan untuk tidak bermain dengan anak-anak tertentu, (3) apa yang dilakukan ketika anak bertengkar dengan teman, dan (4) apa yang membuat anak betengkar dengan temannya. Selain itu juga digunakan data yang berasal dari angket yang diberikan pada 24 guru wali kelas. Data ini mengungkap : (1) hasil pengamatan guru tentang bentuk perilaku seperti apa yang dilakukan siswa ketika berselisih, dan hal-hal apa saja yang menjadi sumber penyebab terjadinya pertengkaran, (2) cara guru menyelesaikan masalah pertengkaran siswa, (3) bagaimana peran guru dalam mengajarkan penanaman nilai-nilai, (4) pendapat guru tentang kemungkinannya dilaksanakan pembelajaran nilai toleransi di Sekolah Dasar, dan (5) visi guru dalam pendidikan di sekolah dasar. Hasil analisis data ditampilkan pada tabel berikut ini.

Tabel 1. Preferensi pemilihan teman bermain

\begin{tabular}{ll}
\hline \multicolumn{1}{c}{ Teman yang diajak bermain } & \multicolumn{1}{c}{ Teman yang dihindari diajak bermain } \\
\hline Teman satu kelas & Teman yang nakal \\
\hline $\begin{array}{l}\text { Di rumah dengan anak yang lebih besar (teman } \\
\text { main sepak bola) }\end{array}$ & $\begin{array}{l}\text { Teman yang dikelas suka ngompasin teman-temannya, } \\
\text { kalau tidak dikasih mengamuk, kadang-kadang buku } \\
\text { temannya disobek. }\end{array}$ \\
\hline Teman usia sebaya & $\begin{array}{l}\text { Teman yang memfitnah ("dia bilang aku suka nyontek } \\
\text { dan dia bilang kalo aku suka 'nggledahi' tasnya teman } \\
\text { sampingku }\end{array}$ \\
\hline
\end{tabular}




\begin{tabular}{ll}
\hline Teman yang baik & Teman yang sering buka-buka rahasia orang lain \\
\hline Teman yang enak diajak main & Temen yang sombong \\
\hline Dengan teman cewek saja & Teman yang pelit \\
\hline $\begin{array}{l}\text { Orang yang lucu, kalo main mau disuruh apa } \\
\text { saja }\end{array}$ & \\
\hline Teman yang rumahnya dekat & \\
\hline Teman yang suka ganti-ganti meminjamkan & \\
mainan & \\
\hline Teman yang suka menolong orang &
\end{tabular}

Tabel 1. menunjukkan bahwa sesuai dengan penjelasan (Santrock, 2002) sebagian besar anak-anak memberikan jawaban dengan cara mengidentifikasikan seseorang berdasarkan karakteristik psikologinya. Dalam hal ini muncul karakteristikkarakteristik psikologis yang disukai anak-anak untuk diajak bermain adalah teman yang baik : baik, enak diajak bermain, lucu, suka bergantian pinjam mainan, dan suka menolong. Sebaliknya karakteristik psikologis seperti, nakal, suka ngompasin, suka ngamuk, suka memfitnah, sombong, pelit, tidak dapat dipercaya adalah karakteristik yang cenderung ditolak untuk bermain bersama. Preferensi pemilihan teman sikap tidak toleran yang ditunjukkan oleh cara penyelesaian konflik dengan kekerasan, baik kekerasan fisik seperti : memukul, berkelahi (dorong-dorongan, jotos-jotosan, cubit-cubitan, jambakjambakan) maupun yang berupa agresif pasif seperti : saling mendiamkan (jothakan), dan mengucilkan teman. Kecenderungan kurang adanya penghargaan terhadap orang lain juga ditemukan melalui jawaban yang menunjukkan ejekan seperti : "Hey jelek... hey bodoh". Walaupun dalam preferensi pemilihan teman tidak muncul deskripsi pemilihan teman berdasarkan karakteristik fisik, namun karakter fisik ini (gendut... item) ternyata menjadi salah satu bahan ejekan.
Hasil pengamatan guru menemukan adanya fenomena siswa membuat kelompok-kelompok sendiri (nge-group, nge-geng). Bila mengingat aspek perkembangan psikososial anak sekolah dasar, usia sekolah dasar sering disebut "usia berkelompok", oleh karena itu hal yang sewajarnya bila siswa berkelompok. Namun demikian, seperti yang dijelaskan oleh (Santrock, 2002) apabila kecenderungan etnosentrisme ini berlebihan akan dapat berkembang suatu prasangka (prejudice) yang kemudian potensial menjadi hambatan dalam kelancaran hubungan sosial, atau bahkan menjadi pangkal pemicu terjadinya konflik. Artinya, bila pembuatan geng atau group ini dilakukan untuk kegiatan positif pengembangan diri maka akan memberi dampak positif pula. Namun, bila terciptanya geng atau group ini dilakukan untuk mengisolir diri dari kelompok lain, atau untuk mengucilkan teman yang ingin bergabung, maka hal ini berdampak negatif menuju berkembangnya etnosentrisme dalam arti negatif.

Hasil analisis data ini menggambarkan adanya kesenjangan antara kenyataan kondisi siswa yang ada dan harapan guru. Fakta ini semakin meyakinkan adanya asumsi bahwa pelajaran PPKn belum menyentuh ranah afektif atau pengembangan kepribadian siswa. Di sisi lain, fakta ini juga memperkuat pendapat (Harefa, 2004) bahwa pengembangan kepribadian tidak 
mungkin dilakukan lewat pengajaran mata pelajaran semata, yang pada dasarnya memang lebih banyak menyangkut soal teori.

Pendapat dan pandangan guru ini pada kenyataannya sulit dilakukan, karena waktu dan perhatian guru lebih banyak tersita untuk menghadapi tuntutan "meliputi kurikulum" yang begitu padat dan penuh dan lebih didominasi pada pengembangan aspek kognitif semata. Pendekatannya pun lebih banyak pendekatan belajar tentang (learning to know) dan masih kurang mengadopsi pendekatan belajar menjadi (learning to be).

Selama ini pembelajaran yang sudah dilakukan oleh guru dalam hal penanaman nilai-nilai adalah berkaitan dengan nilai-nilai berikut ini :

a. Nilai kedisiplinan : dilakukan melalui penetapan peraturan membuang sampah pada tempatnya, datang sekolah tepat waktu, pemberian sanksi bagi yang tidak mengerjakan tugas

b. Nilai tanggung jawab : dilakukan melalui peraturan piket, dan memimpin doa

c. Nilai kejujuran : menguji kejujuran lewat menemukan uang di kelas, kejujuran dalam mengerjakan PR (pekerjaan rumah)

d. Nilai penghargaan : dilakukan dengan pemberian hadiah pada anak yang berprestasi

e. Nilai kasih sayang : menganjurkan menjenguk teman sakit.

\section{Rancangan Modul Pembelajaran} Nilai Toleransi

Pembelajaran adalah upaya untuk membelajarkan siswa, di dalamnya terdapat kegiatan memilih, menetapkan dan mengembangkan metode untuk mencapai hasil pembelajaran yang diinginkan. Dalam pembelajaran menaruh perhatian pada "bagaimana membelajarkan siswa" dan bukan pada "apa yang dipelajari siswa (Uno, 2006). Lebih lanjut, dijelaskan bahwa dalam rancangan atau perencanaan merupakan suatu cara yang memuaskan untuk membuat suatu kegiatan dapat berjalan dengan baik disertai dengan berbagai langkah yang antisipatif guna memperkecil kesenjangan yang terjadi, sehingga kegiatan tersebut mencapai tujuan yang telah ditetapkan.

Pada penyelesaian terhadap masalah rendahnya kemampuan penghargaan terhadap orang lain, kompetensi yang diajukan tidak hanya untuk meningkatkan kemampuan penghargaan terhadap orang lain saja, tetapi juga penghargaan terhadap diri sendiri. Pertimbangan dimunculkannya komponen penghargaan terhadap diri sendiri adalah bahwa penghargaan terhadap diri sendiri perlu dibangun terlebih dahulu sebelum anak belajar menghargai orang lain. Selain itu penghargaan terhadap diri sendiri dipandang perlu untuk membangun konsep diri anak yang positif.

Rincian nama-nama kegiatan, aktivitas materi pembelajaran dan metode selengkapnya ditampilkan pada tabel berikut ini : 
Tabel 2. Aktivitas Materi Pembelajaran dan Metode

\begin{tabular}{|c|c|c|}
\hline Kompetensi & Strategi Penyelesaian Alternatif & Kegiatan yang Dirancang \\
\hline \multirow[t]{2}{*}{$\begin{array}{l}\text { Kemampuan } \\
\text { penghargaan } \\
\text { terhadap orang } \\
\text { lain }\end{array}$} & $\begin{array}{l}\text { Meningkatkan kemampuan } \\
\text { penghargaan terhadap diri sendiri }\end{array}$ & $\begin{array}{l}\text { Peningkatan kemampuan menghargai diri } \\
\text { sendiri (membentuk konsep diri yang positif) }\end{array}$ \\
\hline & $\begin{array}{l}\text { Meningkatkan kemampuan } \\
\text { penghargaan terhadap orang lain }\end{array}$ & $\begin{array}{l}\text { Peningkatan ketrampilan dalam memberi dan } \\
\text { menerima penghargaan dalam pergaulan sosial }\end{array}$ \\
\hline $\begin{array}{l}\text { Kesediaan } \\
\text { menerima } \\
\text { perbedaan }\end{array}$ & $\begin{array}{l}\text { Meningkatkan kemampuan saling } \\
\text { menghargai keragaman }\end{array}$ & $\begin{array}{l}\text { Pengenalan tindakan toleran dan tidak toleran, } \\
\text { serta penghargaan terhadap keragaman }\end{array}$ \\
\hline $\begin{array}{l}\text { Kemampuan } \\
\text { penyelesaian } \\
\text { konflik secara } \\
\text { damai }\end{array}$ & $\begin{array}{l}\text { Meningkatkan kemampuan } \\
\text { penyelesaian konflik secara damai }\end{array}$ & $\begin{array}{l}\text { Peningkatan kemampuan penyelesaian konflik } \\
\text { secara damai. }\end{array}$ \\
\hline \multirow{5}{*}{\multicolumn{2}{|c|}{$\begin{array}{l}\text { Inti dari rancangan pembelajaran } \\
\text { adalah menetapkan metode pembelajaran } \\
\text { yang optimal untuk mencapai hasil } \\
\text { pembelajaran yang diinginkan. Menurut } \\
\text { (Uno, 2006) fokus utama dalam } \\
\text { perancangan pembelajaran adalah pada }\end{array}$}} & pemilihan, penetapan, dan pengembangan \\
\hline & & pembelajaran. \\
\hline & & pembelajaran dalam kegiatan untuk \\
\hline & & mencapai masing-masing kompetensi, \\
\hline & & $\begin{array}{l}\text { selengkapnya dapat dilihat pada tabel } 3 \\
\text { berikut ini. }\end{array}$ \\
\hline
\end{tabular}

Tabel 3. Kompetensi dan metode tiap aktivitas pembelajaran toleransi

\begin{tabular}{|c|c|c|}
\hline Kegiatan \& Materi aktivitasnya & Kompetensi & Metode \\
\hline $\begin{array}{l}\text { Peningkatan kemampuan menghargai diri } \\
\text { sendiri : } \\
\text { 1. } \\
\text { 2. Bintang dalam apel } \\
\text { Berikan Popcorn-nya }\end{array}$ & $\begin{array}{l}\text { Siswa mampu } \\
\text { menghargai diri sendiri }\end{array}$ & Pengamatan terstruktur \\
\hline $\begin{array}{l}\text { Peningkatan ketrampilan dalan memberi dan } \\
\text { menerima penghargaan dalam pergaulan sosial : } \\
\text { 3. Lima kata penjaga hubungan } \\
\text { 4. Penghargaan } \\
\text { 5. Kelihatan dan tidak kelihatan }\end{array}$ & $\begin{array}{l}\text { Siswa memiliki } \\
\text { ketrampilan sosial } \\
\text { dalam memberi dna } \\
\text { menerima penghargaan } \\
\text { dalam pergaulan dengan } \\
\text { orang lin }\end{array}$ & $\begin{array}{ll}\text { - } & \text { Bermain peran } \\
\text { - } & \text { Permainan } \\
\text { - } & \text { Bercerita dan } \\
& \text { peragaan }\end{array}$ \\
\hline $\begin{array}{l}\text { Pengenalan tindakan toleran dan tdak toleran, } \\
\text { serta penghargaan terhadap keragaman : } \\
\text { 6. Nilai sebuah jiwa } \\
\text { 7. Si pendek dan Si Jangkung }\end{array}$ & $\begin{array}{l}\text { Siswa mengenal } \\
\text { tindakan toleran dn } \\
\text { tidak toleran serta } \\
\text { mampu saling } \\
\text { menghargai dalam } \\
\text { keragaman }\end{array}$ & $\begin{array}{ll} & \text { Pengamatan } \\
& \text { terstruktur bercerita }\end{array}$ \\
\hline $\begin{array}{l}\text { Peningkatan kemampuan penyelesaian konflik } \\
\text { secara damai : } \\
\text { 8. Di balik kemarahan } \\
\text { 9. Tanganku untuk... } \\
\text { 10. Strategi menyelesaikan konflik }\end{array}$ & $\begin{array}{l}\text { Siswa memiliki } \\
\text { pengetahuan, } \\
\text { pengalaman damai bagi } \\
\text { diri sendiri dan orang } \\
\text { lain serta mampu } \\
\text { menyelesaikan konflik } \\
\text { secara damai }\end{array}$ & $\begin{array}{ll} & \text { Eksplorasi } \\
\text { pengalaman pribadi } \\
\text { - }\end{array}$ \\
\hline
\end{tabular}

Masing-masing materi ini dapat dialokasikan dalam satu pertemuan dengan waktu masing-masing pertemuan bisa berbeda-beda, dengan estimasi waktu direncanakan berkisar 30-45 menit. Pelaksanaan kegiatan dilakukan oleh guru di sekolah dasar. Kegiatan yang dilakukan tidak memerlukan ruang khusus seperti ruang kelas, namun juga dapat dilakukan di luar ruangan sepanjang tersedia tempat bagi anak untuk dapat mengerjakan aktivitasnya. Penentuan waktu pelaksanaan juga tidak ditentukan, sehingga kegiatan ini bersifat 
sangat fleksibel dan dapat dilakukan pada setiap waktu yang dianggap memungkinkan untuk melakukan kegiatan pembelajaran.

Modul diharapkan dapat digunakan secara fleksibel sesuai kondisi sekolah masing-masing. Sekolah dapat memilih dilaksanakan sebagai ekstrakurikuler, intrakurikler, atau disisipkan dalam mata pelajaran tertentu. Apabila dikehendaki dapat pula digunakan sebagai kegiatan guru bimbingan konseling. Pelaksanaan kegiatan pembelajaran ini sebaiknya dilakukan sesuai dengan urutan materi yang disusun dalam kegiatan pembelajaran, yaitu mulai dari materi penghargaan terhadap diri sendiri, penghargaan terhadap orang lain, penghargaan terhadap perbedaan budaya dan penyelesaian konflik secara damai.

Tabel 4. Hasil penilaian terhadap Modul Pembelajaran Toleransi

\begin{tabular}{llllll}
\hline \multirow{2}{*}{ No } & \multicolumn{1}{c}{ Aktivitas } & \multicolumn{4}{c}{ Skor Reviewer } \\
\cline { 3 - 6 } & & I & II & III & Rerata \\
\hline 1 & Bintang dalam Apel & 85 & 85 & 75 & 81,66 \\
\hline 2 & Berikan Popcorn-nya & 75 & 85 & 50 & 70 \\
\hline 3 & Lima kata penjaga hubungan & 80 & 85 & 100 & 88,33 \\
\hline 4 & Penghargaan & 75 & 85 & 50 & 70 \\
\hline 5 & Kelihatan dan tidak kelihatan & 60 & 90 & 100 & 88,33 \\
\hline 6 & Nilai sebuah Jiwa & 60 & 85 & 25 & 56,66 \\
\hline 7 & Si Pendek dan Si Jangkung & 70 & 90 & 100 & 86,33 \\
\hline 8 & Di balik kemarahan & 75 & 90 & 25 & 63,33 \\
\hline 9 & Tanganku untuk... & 70 & 90 & 50 & 70 \\
\hline 10 & Strategi menyelesaikan konflik & 70 & 90 & 50 & 70 \\
\hline \multicolumn{2}{c}{ Nilai rerata } & 72 & 87,5 & 62,5 & 73,99 \\
\hline
\end{tabular}

Tabel 4 memperlihatkan bahwa pada umumnya aktivitas dinilai tepat untuk mengungkapkan tujuan yang ingin dicapai. Aktivitas yang paling kecil nilai ketepatannya adalah aktivitas "nilai sebuah jiwa", yang mendapatkan rerata skor 56,66. Sebaliknya, aktivitas yang memiliki ketepatan paling tinggi adalah aktivitas "lima kata penjaga hubungan", dengan rerata skor 83,33 . Selain penilaian secara kuantitatif, diperoleh juga
Hal ini berdasarkan pemikiran bahwa setiap materi akan mempermudah penyampaian materi selanjutnya.

3. Materi Aktivitas dalam Modul Pembelajaran Toleransi

Diskusi review model Pembelajaran Toleransi dihadiri oleh 6 orang peserta, yang terdiri dari tiga orang reviever dan tiga orang tim peneliti. Pakar yang diminta untuk mengkaji modul adalah yang memiliki kompetensi kajian bidang multikultural, pakar bidang pendidikan dan praktisi bidang psikolog anak. Kajian difokuskan pada evaluasi terhadap materi aktivitas, ketepatan strategi atau metode yang dipilih dan visibilitas modul bila diterapkan di sekolah dasar. Hasil penilaian reviewer ditampilkan pada tabel 4 berikut ini : 
melukiskan 3 hal sekaligus. Pertama similaritas (semua buah apel). Kedua, differences (warna dan bentuk apel). Ketiga, uniqveness(bijih apel, potensi individu). Sementara untuk materi "berikan popcorn-nya" memiliki kemanfaatan yang jelas bagi eksplorasi diri dalam pengembangan pribadi. Hal ini tertuang dalam penugasan membuat tulisan dengan topik "aku ingin menjadi..." atau topik "yang paling kusukai pada diriku". Tulisan siswa yang merupakan ungkapan perasaan dan pikirannya ini, di satu sisi akan menjadi data dokumentasi siswa yang bermanfaat bagi guru dalam membantu pengembangan diri dan pemahaman diri siswa. Di sisi lain bagi siswa itu sendiri akan bermanfaat sebagai tempat untuk belajar mengenali dan menuangkan pikiran dan perasaannya tentang dirinya sendiri. Hal ini penting untuk pengembangan konsep diri siswa.

2. Kekuatan komponen penghargaan terhadap orang lain, terletak pada materi "lima kata penjaga hubungan", yang memiliki posisi urutan tertinggi (skor 83,33) dalam modul pembelajaran toleransi. Materi ini dinilai sudah mencerminkan problem yang biasa ditemukan dalam adat pergaulan sosial, yaitu berkaitan dengan ketrampilan sosial dalam hal permintaan maaf, penyampaian rasa terima kasih, permintaan tolong, permisi, dan menyampaikan ucapan selamat. Untuk materi "kelihatan dan tidak kelihatan" (skor 83,33 menduduki urutan ketiga) memiliki visibilitas untuk dipraktekkan.
Aktivitas ini dinilai cukup konkrit dan jelas, bahkan berpotensi menggabungkan nilai-nilai lain, tidak hanya kejujuran. Sumbangan terkecil untuk komponen penghargaan terhadap orang lain ini diberikan oleh materi "Penghargaan" (skor 70). Materi ini cukup konkrit dan jelas dalam melatih dan memancing timbulnya sikap menerima sekaligus memberi rasa hormat (respect) pada dan dari orang lain.

3. Kekuatan komponen penghargaan terhadap perbedaan budaya terletak pada materi "Si Pendek dan $\mathrm{Si}$ Jangkung" yang menduduki urutan kedua (skor 86,66) dalam modul pembelajara toleransi. Gambaran tentang tindakan toleransi dan intoleransi muncul jelas pada materi "Si Pendek dan Si Jangkung", walaupun menurut salah satu pakar yang mengkaji modul ini, dinilai masih dalam tataran perbedaan individual (belum pada keragaman budaya). Oleh karena itu perbaikan dilakukan pada diskusi agar penjelasan diperluas ke arah keragaman budaya. Namun, untuk anak usia sekolah dasar dan untuk tahap awal kiranya tetap perlu diperkenalkan dulu kesediaan menerima perbedaan dalam tataran individual. Materi lainnya adalah "nilai sebuah jiwa" juga tepat untuk menyampaian materi saling menghargai pada konteks perbedaan individu, walaupun materi ini memiliki sumbangan yang paling kecil (skor 56,66) dibanding materimateri lain dalam modul pembelajaran toleransi ini. 


\section{SIMPULAN}

Penelitian ini menghasilkan beberapa kesimpulan sebagai berikut. Pertama, ada kesenjangan antara harapan guru dengan kondisi siswa saat ini. Di satu sisi, kondisi siswa menunjukkan adanya berbagai permasalahan interaksi sosial siswa selama ini, yang apabila ditelusuri berakar pada rendahnya komptensi dalam hal : (1) kemampuan penghargaan terhadap orang lain, (2) kesediaan menerima perbedaan, dan (3) kemampuan penyelesaian konflik secara damai. Di sisi lain, cita-cita atau harapan guru terhadap siswa adalah agar siswa mengerti sopan santun, siswa tidak hanya berhasil dalam akademik saja tetapi juga dalam segi kepribadian luhur, siswa menghayati nilai-nilai takut pada Tuhan, siswa memiliki kepekaan diri sejak dini terhadap lingkungan, guru ingin dapat memperbaiki sikap siswa, dan bukan hanya memberi materi pelajaran akademik saja,dan guru ingin mengajarkan tatakrama dan sopan santun pada siswa. Untuk mengatasi kesenjangan ini maka pengajuan model pembelajaran nilai toleransi merupakan penyelesaian alternatif yang relevan.

Kedua, modul pembelajaran nilai toleransi disusun dengan tujuan agar siswa memiliki kompetensi : (1) kemampuan menghargai diri sendiri, (2) ketrampilan sosial dalam memberi dan menerima penghargaan dalam berinteraksi dengan orang lain, (3) kemampuan mengenal tindakan toleran dan tidak toleran serta mampu saling menghargai dalam keragaman, dan (4) kemampuan menyelesaikan konflik secara damai. Secara keseluruhan modul terdiri dari empat komponen yang mencakup 10 aktivitas pembelajaran.
Metode penyampaian yang digunakan terdiri dari: pengamatan terstruktur, eksplorasi pengalaman pribadi, modeling, permainan, dan bermain peran serta bercerita.

Ketiga, semua guru memandang perlu ada pembelajaran toleransi di sekolah dasar, walaupun terdapat variasi perbedaan strategi penyampaian, yakni sebagai kegiatan intrakurikuler, ekstrakurikuler, dan disisipkan dalam mata pelajaran. Walaupun secara konseptual modul dinilai telah memiliki kemampuan untuk mencapai tujuan pembelajaran toleransi, namun secara empiris modul pembelajarn toleransi ini belum teruji efektivitasnya terhadap peningkatan keterampilan sosial siswa. Oleh karena itu, disarankan untuk dilakukan penelitian lebih lanjut sebagai uji empiris efektivitas modul ini, selain juga untuk mengetahui keterkaitannya dengan strategi pengorganisasian pembelajaran, strategi penyampaian pembelajaran dan strategi pengelolaan pembelajaran bila modul ini diaplikasikan oleh guru sekolah dasar.

\section{DAFTAR RUJUKAN}

Green, P. (2001). Teaching Kids Tolerance. Retrieved from http://www.wholefamily.com/: http://www.wholefamily.com/abo utyourkids/children_prejudice.ht $\mathrm{ml}$

Harefa, A. (2004). Menjadi Manusia Pembelajar. Jakarta: Penerbit Harian Kompas.

Ling, Y. d. (2002). Interaksi Sosial di Sekolah dan Harga Diri Pelajar Sekolah Mnenengah Umum. Phronesis, Jurnal Ilmiah Psikologi Terapan, Vol. 4 No.7. Hal 35-49. 
Nuswantari. (2017). Implementasi Perlindungan Hukum Terhadap Perempuan Korban Kekerasan Dalam Rumah Tangga. Journal Citizenship Prodi Pancasila dan Kewarganegaraan, Vol 5. No. 2.

Patnani, M. (2005). Kegiatan Pengajaran Nilai Toleransi untuk Anak Usia 4-6 Tahun. Pascasarjana Fakultas Psikologi Universitas Indonesia.

Prawiradilaga, D. (2007). Prinsip Desain Pembelajaran . Jakarta: Kencana Prenada Media Group.

Purwanti, E. (2007). Pengaruh Pemberian Dongeng Cerita Pewayangan terhadap Penalaran Moral Anak. . Skripsi. Surakarta:
Fakultas Psikologi Universatas Muhammadiyah Surakarta.

Salim, H. (2003). Belajar Bersama Pluralisme : $\quad$ Sekelumit Pengalaman. Wacana, 223.

Santrock, J. W. (2002). Life - Span Development. Perkembangan MAsa Hidup . Jakarta : Erlangga.

Uno, H. B. (2006). Orientasi baru dalam Psikologi Pembelajaran. Jakarta : Bumi Aksara.

Vogt, P. W. (1997). Learning to Live With Diversity and Difference. Tolerance and Education. 